\title{
"Liquidity, leverage, and solvency: What affects profitability of industrial enterprises the most?"
}

\begin{tabular}{|c|c|}
\hline \multirow{3}{*}{ AUTHORS } & Maha D. Ayoush (i) \\
\hline & Ahmad A. Toumeh (iD) \\
\hline & Khaled I. Shabaneh \\
\hline ARTICLE INFO & $\begin{array}{l}\text { Maha D. Ayoush, Ahmad A. Toumeh and Khaled I. Shabaneh (2021). Liquidity } \\
\text { leverage, and solvency: What affects profitability of industrial enterprises the } \\
\text { most?. Investment Management and Financial Innovations, 18(3), 249-259. } \\
\text { doi:10.21511/imfi.18(3).2021.22 }\end{array}$ \\
\hline DOI & http://dx.doi.org/10.21511/imfi.18(3).2021.22 \\
\hline RELEASED ON & Wednesday, 08 September 2021 \\
\hline RECEIVED ON & Wednesday, 10 February 2021 \\
\hline \multirow[t]{2}{*}{ ACCEPTED ON } & Monday, 30 August 2021 \\
\hline & $(\mathrm{cc}) \overline{\mathrm{EY}}$ \\
\hline LICENSE & $\begin{array}{l}\text { This work is licensed under a Creative Commons Attribution } 4.0 \text { International } \\
\text { License }\end{array}$ \\
\hline JOURNAL & "Investment Management and Financial Innovations" \\
\hline ISSN PRINT & $1810-4967$ \\
\hline ISSN ONLINE & $1812-9358$ \\
\hline PUBLISHER & LLC “Consulting Publishing Company "Business Perspectives" \\
\hline FOUNDER & LLC "Consulting Publishing Company "Business Perspectives" \\
\hline
\end{tabular}

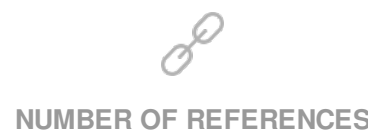

26
NUMBER OF FIGURES

3
NUMBER OF TABLES

6

(C) The author(s) 2021. This publication is an open access article. 


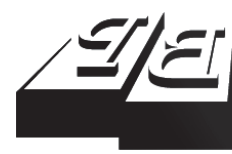

\section{BUSINESS PERSPECTIVES}

LLC "CPC "Business Perspectives" Hryhorii Skovoroda lane, 10, Sumy, 40022, Ukraine www.businessperspectives.org
Received on: $10^{\text {th }}$ of February, 2021 Accepted on: $30^{\text {th }}$ of August, 2021 Published on: $8^{\text {th }}$ of September, 2021

() Maha D. Ayoush, Ahmad A. Toumeh, Khaled I. Shabaneh, 2021

Maha D. Ayoush, Ph.D. Assistant Professor, Al-Zaytoonah University of Jordan, Jordan. (Corresponding author)

Ahmad A. Toumeh, Ph.D. Assistant Professor, Al-Zaytoonah University of Jordan, Jordan.

Khaled I. Shabaneh, Master, Research Assistant, Al-Zaytoonah University of Jordan, Jordan.

\section{LIQUIDITY, LEVERAGE,}

AND SOLVENCY: WHAT AFFECTS PROFITABILITY OF INDUSTRIAL ENTERPRISES THE MOST?

\begin{abstract}
The purpose of this paper is to show the relative impact of liquidity, leverage, and solvency on profitability of industrial enterprises listed on the Amman Stock Exchange to ascertain which of them has the most effect on profitability. To reach the objectives of this study, 44 Jordanian industrial companies are examined from 2012 to 2018. Return on assets (ROA) and return on equity (ROE) are examined as measures of performance, current ratio and quick ratio as measures of liquidity, debt ratio and debt to equity ratio as measures of leverage, and the interest coverage ratio as a measure of financial solvency. Multiple regression analysis was used to check the hypotheses. A negative and statistically significant impact was found at the $1 \%$ level between financial leverage and profitability. At the same time, findings did not show the same for the effect of liquidity and solvency on profitability. In addition, leverage has the highest relative impact among independent variables on profitability, followed by solvency and then liquidity. Moreover, it is indicated that company size is a control variable of the effect between liquidity, leverage, and solvency on performance. Thus, it is concluded that management of industrial companies should reduce dependence on debt to finance companies to achieve the highest possible returns; it is recommended to maintain an acceptable level of liquidity to ensure the continuity of companies and attention to the level of solvency within companies to maintain a high financial performance.
\end{abstract}

\section{Keywords Amman Stock Exchange, Jordanian industrial companies, relative impact, $\mathrm{ROA}, \mathrm{ROE}$}

\section{JEL Classification $\quad$ L25, M41}

\section{INTRODUCTION}

The industrial sphere is one of the most vital and profitable spheres in the Jordanian economy that contributes to the growth of the economy domestically and internationally since it contributes to establishing financial stability in the country and creating job opportunities, which increases its importance. Therefore, this study examines Jordanian industrial enterprises and concentrates on their profitability.

Profitability is the primary goal that companies seek to achieve to ensure their viability and continuity. Hence, increasing the profitability of companies depends on their ability to manage their sources of funds optimally (Kanaan \& Saoud, 2018). In order to achieve the performance that companies desire, they must maintain acceptable levels of liquidity and achieve a balance between internal and external sources of financing. Companies should also work to ensure their business runs smoothly, reinvest money in income-generating projects for continuity, and ensure a competitive position (Kanaan \& Saoud, 2018; Dahiyat, 2016).

Liquidity is one of the important elements that ensure the continuity of companies, as companies that do not have sufficient liquidity may not be able to pay their short-term obligations to their suppliers and 
provide services and goods on time, which affects their reputation and may result in bankruptcy due to the company's inefficiency in managing its assets optimally (Yusoff, 2017). Financing by borrowing results in what is called leverage (Aliwi, 2019). Although there are advantages to corporate leverage for the tax savings that it achieves, increasing dependence on external financing sources without efficiency in their use exposes the company to serious consequences (Kanaan \& Saoud, 2018). The concept of financial solvency is also one of the basic concepts that management of industrial firms is interested in to measure the company's efficiency in covering its long-term obligations (Owais, 2016).

This study investigates the effect of leverage, solvency, and liquidity on profitability of industrial enterprises to find out which of these factors affects profitability the most. From this standpoint, the importance of this study lies through conceptual coverage of liquidity, leverage, and solvency, and examining their influence on profitability of Jordanian industrial enterprises.

This study has great importance for the parties that benefit from its results such as managers, investors, decision-makers, the financial market, financial analysts, and lenders.

The findings of this paper can be used by managers and shareholders, as well as decision-makers of industrial firms in Jordan. In addition, this study is a contribution to literature, since similar investigations have not been implemented before and there was no previous practical evidence in terms of showing the influence of leverage, solvency, and liquidity on profitability of industrial companies in Jordan. The paper analyzes a group of industrial enterprises after the financial crisis period, whereas Jordan is located in the Middle East and North Africa (MENA) area, and not included in the list of highly industrialized countries, and thus, is largely unstudied (Saleh et al., 2020; Bitar et al., 2016)

\section{LITERATURE REVIEW}

To review the literature in this field and shed light on the effective contribution of this study, a detailed review of previous studies that have been done in this field was conducted. The review helped to discover the shortcomings in the previous literature, use it in developing the study model and in formulating research hypotheses.

Based on the above, the most important previous studies that relate to topics similar to the subject of this study were investigated.

Nguyen and Nguyen (2020) examined the determinants of profitability for the companies listed on the Vietnamese Stock Exchange by examining a sample of 1,343 Vietnamese companies classified in six different industries for the period 2014-2017. The determinants examined are company size, liquidity, solvency, leverage, and financial adequacy. It was found that company size, financial adequacy, and solvency have a positive effect on both ROA and ROS while having a negative one on ROE. The leverage showed a positive effect on ROA, but it had a negative one on ROE and ROS. The results also showed that liquidity has a negative effect on ROS whereas a positive one on both ROE and ROA, which is similar to Madushanka and Jathurika (2018) who studied listed manufacturing companies in Sri Lanka. Shahzad et al. (2015) and Sarwat et al. (2017) found similar results in Pakistan. However, different results were achieved by Mohanty and Mehrotra (2018), who found a significant negative influence of liquidity on ROA in India, and Bhatt and Verghese (2018), who found no significant influence of liquidity on ROA in Nepal.

In Jordan, Aliwi (2019) researched the effect of financial leverage on financial performance of 49 Jordanian public shareholding firms during 20132017. Debt to equity ratio was used to estimate the financial leverage; both ROE and ROA were used to estimate financial performance. An effect of financial leverage on financial performance as measured by ROE was found, while there was no impact of financial leverage on financial performance as measured by ROA. 
In addition, Durrah et al. (2016) examined a sample of eight food industrial companies during 2012-2014 to explore the links between liquidity (expressed by cash ratio, quick ratio, and current ratio) and financial performance (expressed by ROA). The results showed positive relations between ROA and liquidity.

Owais (2016) studied the impact of liquidity and solvency on the profitability of 62 Jordanian industrial enterprises during 2012-2014. The results showed no statistically significant relationship between profitability and liquidity. However, a positive impact of solvency (measured by the percentage of ownership) on profitability (measured by ROE and gross profit from operations to revenue) was found. The findings also showed a negative effect of solvency (measured by the debt ratio) on profitability (measured by ROE and gross profit from operations to revenue). A similar study conducted by Yusoff (2017) examined the relationship among profitability, solvency, and liquidity of Malaysian public-listed consumer goods firms by using a sample of 116 companies during 2012-2015. The results indicated that liquidity (measured by the quick ratio) has a significant and positive impact on profitability, and the current ratio has an insignificant and negative impact on profitability. However, the results showed that solvency has no significant effect on profitability.

Al-Ali (2018) investigated the relationships among financial leverage, liquidity, and profitability of companies listed on the Damascus Stock Exchange. To achieve the research objectives, profitability was measured by both ROE and ROA, and liquidity was measured by both the current ratio and the cash flow rate from operating activities. A sample of four service and industrial enterprises was studied during 2012-2016. It was found that there is a negative effect of financial leverage on liquidity while a positive one of financial leverage on company profitability. This result contradicts Al-Jafari and Samman (2015) who found a negative impact of financial leverage on profitability studying 17 industrial companies in Oman during 2006-2013. Similarly, Ali (2014) studied leverage and financial performance of 20 chemical companies in Pakistan during 2006-2013 and found a negative effect between ROE and the debt-to-equity ratio. Similarly, Chang et al. (2019) showed a negative influence of debt ratio on ROA for a sample of companies from Hong Kong, Singapore, South Korea, and Taiwan. However, Akenga (2017), Kebewar and Shah (2012), and Baum et al. (2006) found that debt has no significant impact on profitability.

Rudin et al. (2016) examined the effect of leverage and liquidity on profitability of real estate companies listed on the Indonesian Stock Exchange during 2005-2010. It was found that liquidity has a partial impact on profitability while it showed a significant impact of leverage on profitability. Sudiyanto et al. (2020) investigated the impact of profitability on the firm value of Indonesian manufacturing companies from 2016 to 2018. The findings revealed that firm size does not have a direct influence on firm value through profitability. Furthermore, findings revealed that the impact of managerial ownership and firm size on profitability is positive. Finally, company size and profitability had a positive impact on firm valuation, but the capital structure and managerial ownership had a negative effect.

The literature review has shown mixed results for the relationship among liquidity, leverage, solvency, and profitability. Therefore, it is necessary to conduct more studies regarding this topic to ascertain which of the variables are more influential on profitability and has the greatest effect. No previous study was conducted in Jordan to examine the relative impact of the variables examined in this study. Moreover, this study covered a recent period, between 2012 and 2018, which increases the importance and relevance of the study, especially taking into account the global financial crises.

Based on this, the research hypotheses are presented in the following section.

\section{HYPOTHESES AND METHODS}

The paper is a descriptive and analytical study that aims to test the hypotheses and state the results and recommendations of the study resulting from the relative influence of liquidity, leverage, and solvency on the profitability of the industrial enterprises listed on the Amman Stock Exchange. 
To achieve the study goals, the following hypotheses are tested:

H01: Liquidity, solvency, and leverage have no statistically significant impact on profitability of Jordanian industrial enterprises listed on the Amman Stock Exchange as measured by ROA.

H01-1: Liquidity has no statistically significant impact on $R O A$.

H01-2: Leverage has no statistically significant impact on $R O A$.

H01-3: Solvency has no statistically significant impact on $R O A$.

H02: Leverage, solvency, and liquidity have no statistically significant impact on profitability of Jordanian industrial enterprises listed on the Amman Stock Exchange as measured by ROE.

H02-1: Liquidity has no statistically significant impact on ROE.

H02-2: Leverage has no statistically significant impact on ROE.

H02-3: Solvency has no statistically significant impact on ROE.
The study population consists of all the industrial enterprises listed on the Amman Stock Exchange from 2012 to 2018; the total number is 56 companies. As for the study sample and its data, it is chosen based on the exclusion of companies that are subject to mergers or acquisitions by other companies, liquidated or suspended from trading during the study period. In addition, all companies whose full data has not been obtained, including those that are listed for trading in the market after 2012, are excluded.

Consequently, the final size of the study sample reached 44 industrial companies. Panel data for the sample over the seven years from 2012 to 2018 is examined to assess the effect of independent variables (liquidity, leverage, and solvency) on the dependent variable (profitability) with the control variable (the size of the company).

Figure 1 shows the relationship between independent variables represented by liquidity, leverage, and solvency, the dependent variable represented by profitability, and the control variable represented by the size of the company.

This study applied the quantitative research method by examining two regression models:

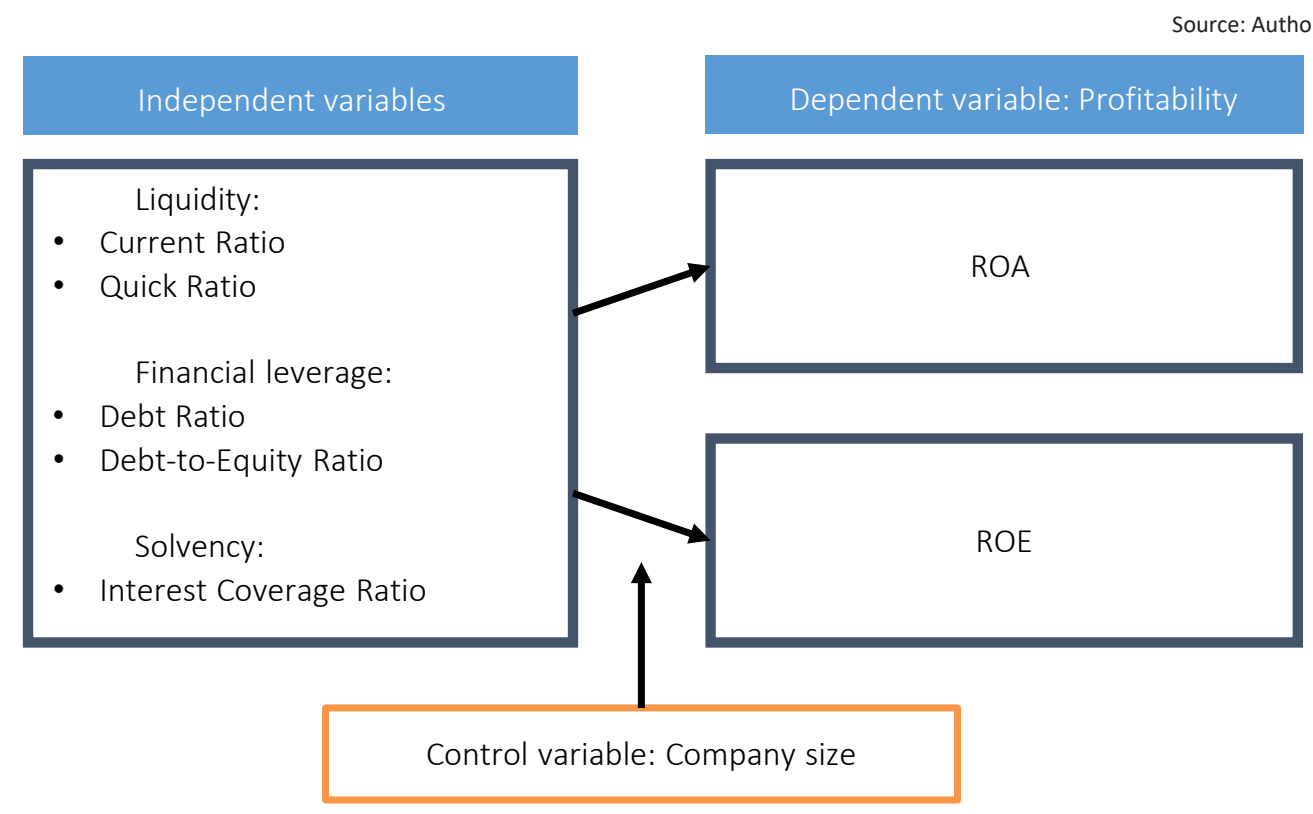

Figure 1. The study model 


$$
\begin{aligned}
& \operatorname{ROA}_{i, t}=\alpha_{0}+\alpha_{1} \operatorname{LIQUID}_{i, t}+ \\
& +\alpha_{2} \text { QUICK }_{i, t}+\alpha_{3} \text { DEBT }_{i, t}+ \\
& +\alpha_{4} \text { DEBTE }_{i, t}+\alpha_{5} \operatorname{INTREST}_{i, t}+ \\
& +\alpha_{6} \operatorname{SIZE}_{i, t}+\varepsilon_{i, t} .
\end{aligned}
$$

and

$$
\begin{aligned}
& \operatorname{ROE}_{i, t}=\alpha_{0}+\alpha_{1} \text { LIQUID }_{i, t}+ \\
& +\alpha_{2} \text { QUICK }_{i, t}+\alpha_{3} \text { DEBT }_{i, t}+ \\
& +\alpha_{4} \text { DEBTE }_{i, t}+\alpha_{5} \text { INTREST }_{i, t}+ \\
& +\alpha_{6} \text { SIZE }_{i, t}+\varepsilon_{i, t} .
\end{aligned}
$$

where: $\alpha_{0}, \alpha_{1}, \alpha_{2}, \alpha_{3}, \alpha_{4}, \alpha_{5}$, and $\alpha_{6}$ are correlation coefficients, $\varepsilon_{i, t}$ is error of company $i$ in year $t, R O A$ - is the return on assets that indicates asset profitability, and is measured by net income/ average total assets, $R O E$ - is the return on equity that indicates profitability of equity, and is measured by (net income-preferred dividends)/ average total equity, LIQUID - is the current ratio (C.R) that indicates liquidity, and is measured by current assets/current liabilities, QUICK - is the quick ratio (Q.R) that indicates liquidity, and is measured by (current assets-inventory)/current liabilities, $D E B T$ - is the debt ratio (D.R) that indicates financial leverage, and is measured by total liabilities/total assets, DEBTEQ - is the debt-to-equity ratio $(\mathrm{D} / \mathrm{E})$ that indicates financial leverage, and is measured by total liabilities/total equity, INTREST - is the interest coverage ratio (I.C.R) that indicates financial solvency, and is measured by Income before interest and tax/ interest expense, SIZE - is the control variable that indicates the company size, and is measured by the natural logarithm of total assets.

\section{DATA ANALYSIS AND RESULTS}

\subsection{Descriptive statistics of the study variables}

Table 1 displays the results of the descriptive tests, which indicate the arithmetic mean, the median, the standard deviation, upper and lower values of the study variables.

Table 1 shows that in general, concerning the dependent variables, ROE and ROA, the results are as follows:

- For the dependent variable, ROE ratio, the mean value is -15.5351 , while the standard deviation is 19.857 . As for the lowest value, it indicates -65.86 , while the highest value indicates 51.010, while the median value is 3.18 .

- For the dependent variable, ROA ratio, the value of the arithmetic mean is 1.820 , while the standard deviation is 10.036. As for the lowest value, it indicates -60.53 , while the highest value indicates 38.4 , and the median value is 2.91 .

\subsection{Multi-collinearity test}

This analysis aims to find out the extent of the problem of high cross-correlations (multi-collinearity) between variables of the multiple regres-

\begin{tabular}{|c|c|c|c|c|c|}
\hline Variable & Mean & Median & Maximum & Minimum & Standard deviation \\
\hline$R O E$ & -15.5351 & 3.180000 & 51.010 & -68.56 & 19.857 \\
\hline$R O A$ & 1.820455 & 2.910000 & 38.40000 & -60.53 & 10.03652 \\
\hline$C . R$ & 2.525065 & 1.925000 & 12.83000 & 0.020000 & 2.065812 \\
\hline Q.R & 1.672870 & 1.167500 & 10.08400 & 0.020000 & 1.582875 \\
\hline$D . R$ & 33.94253 & 31.40000 & 99.82000 & 0.400000 & 20.09324 \\
\hline$D / E$ & 2.861773 & 0.457500 & 745.1790 & -83.41 & 42.71286 \\
\hline I.C.R & 123.8871 & 1.320000 & 786.04 & -3.56 & 51.067 \\
\hline Size & 7.431176 & 7.349684 & 9.083311 & 5.706837 & 0.577357 \\
\hline
\end{tabular}
sion model, and for this purpose, the Pearson Correlation test is used to examine multiple regression models to ensure that there are no high inter-correlations between the independent variables using a matrix of cross-correlations between independent variables. Having a correlation rate

Table 1. Descriptive statistics of the study variables 
Table 2. Matrix of cross-correlations between independent variables

\begin{tabular}{|c|c|c|c|c|c|c|}
\hline Variable & D.R & $D / E$ & I.C.R & COMPANY SIZE & Q.R & C.R \\
\hline$D \cdot R$ & 1 & & & & & \\
\hline$D / E$ & 0.181799 & 1 & & & & \\
\hline I.C.R & -0.050468 & -0.005853 & 1 & & & \\
\hline COMPANY SIZE & 0.117157 & -0.034636 & 0.040827 & 1 & & \\
\hline$Q . R$ & -0.595629 & -0.046244 & 0.007293 & 0.114676 & 1 & \\
\hline C.R & -0.634997 & -0.054372 & 0.016408 & 0.061945 & 0.22698 & 1 \\
\hline
\end{tabular}

of more than $80 \%$ between any two or more variables is a high correlation, and this leads to distorting the relationship between one of the two independent variables with the dependent variable (Gujarati, 2009). In order to verify the absence of such correlations, a matrix is prepared for the reciprocal correlations between the variables of the independent study (Table 2).

It is noted from Table 2 that there is no problem of high cross-correlations affecting the results of the regression. The highest correlation value reached $63.49 \%$, which is an inverse correlation between the current ratio and the debt ratio.

\subsection{Autocorrelation test}

Autocorrelation is the existence of a relationship between the successive random errors computed from the regression model defined by the least-squares method. It can result in problems, which cannot be mentioned here. To check the autocorrelation, the correlogram test is used; it measures the correlation between error limits in a single segment (for the time series), where the existence of a subjective correlation is judged if the test value ( $Q$-stat) is of a significant level (Prob.) less than 0.05 (Table 3).

Table 3. $Q$-Stat autocorrelation test for the remainder of the regression equation

\begin{tabular}{l|c:c}
\hline \multicolumn{1}{c|}{ Method } & Q-Stat & Prob.** \\
\hline ROA & 13.901 & 0.001 \\
ROE & 13.905 & 0.003 \\
\hline
\end{tabular}

Table 3 shows that there is no self-correlation in all the study models, as the significance value was less than $5 \%$ in all models.

\subsection{Hausman test results}

One of the most important assumptions of the regression equation in the Panel Data Analysis method is an indication of whether the regression equation follows a fixed effect or a random effect. The difference between them is the difference between the static segments of each variable to indicate its specificity as it is in the fixed effect model, while in the random effect model the difference is in the random error. The data packets are usually balanced (data of all variables) and it is expected that the fixed effect model will work better in this case, and when they are not balanced, it is better to use the random effect model. However, the best way to choose the most suitable model in the analysis is by using the Hausman test, where the acceptance of the null hypothesis of the test indicates the use of the random effect, while the acceptance of the alternative hypothesis of the test indicates that the fixed effect model is the most suitable. Table 4 displays the result of the Hausman test to show the most appropriate model for the multiple regression equation.

Table 4. Hausman test results

\begin{tabular}{c|c|c:c}
\hline $\begin{array}{c}\text { Test } \\
\text { summary }\end{array}$ & $\begin{array}{c}\text { Chi-Square } \\
\text { Sta }\end{array}$ & $\begin{array}{c}\text { Chi-Square } \\
\text { d.f. }\end{array}$ & Prob. \\
\hline ROA & 18.074123 & 6 & 0.0060 \\
\hdashline ROE & 18.073067 & 6 & 0.0061 \\
\hline
\end{tabular}

It is evident from Table 4 that the fixed estimates model is the most appropriate in this case, as the significance value of the Hausman test was less than $5 \%$ in all models, which means accepting the alternative hypothesis that states the use of the fixed effect method.

\subsection{Hypotheses testing}

Table 5 presents the outcomes of regression analysis of the effect of the independent variables on the dependent variable (ROA), where the multiple regression equation was adopted using the method of constant estimates as indicated by the Hausman test. 
Table 5. Results of H01-1-H01-3 testing

\begin{tabular}{|c|c|c|c|c|}
\hline \multicolumn{5}{|c|}{ The dependent variable: ROA } \\
\hline Variable & Coefficient & Std. Error & t-Statistic & Prob. \\
\hline C & -103.4525 & 29.831 & -3.467953 & $0.0006^{* * *}$ \\
\hline$C . R$ & -0.8507 & 1.059325 & -0.803059 & 0.4243 \\
\hline$Q . R$ & 0.59229 & 0.740128 & 0.800253 & 0.4227 \\
\hline$D . R$ & -0.35995 & 0.044701 & -8.052376 & $0.0000 * * *$ \\
\hline$D / E$ & -0.040107 & 0.009012 & -4.450149 & $0.0000 * * *$ \\
\hline I.C.R & 0.000353 & 0.000262 & 1.346963 & 0.1792 \\
\hline C.SIZE & 15.81031 & 4.062164 & 3.892089 & $0.0001^{* * *}$ \\
\hline$R$-squared & \multicolumn{4}{|c|}{0.692} \\
\hline $\begin{array}{l}\text { Adjusted } \\
R \text {-square }\end{array}$ & \multicolumn{4}{|c|}{0.634} \\
\hline F-statistic & \multicolumn{4}{|c|}{11.856} \\
\hline Prob. & \multicolumn{4}{|c|}{$0.0000^{* * *}$} \\
\hline
\end{tabular}

Note: $*, * *$, and $* * *$ denote acceptance of the hypothesis at the $10 \%, 5 \%$, and $1 \%$ levels, respectively.

It appears from Table 5 the acceptance of the statistical model, as the value of Sig is reached. The F-Statistics coefficient is 0.00000 , this indicates that the statistical model is acceptable at the level of $1 \%$ and that the study variables are consistent with each other to a high degree. The adjusted R2 value also indicated $63.4 \%$, which means that the independent variables in the study model explained an amount of $63.4 \%$ of the change in ROA. Based on the foregoing, the main null hypothesis is rejected, "Liquidity, leverage, and financial solvency have no statistically significant impact on profitability of Jordanian industrial enterprises listed on the Amman Stock Exchange as measured by ROA" and the alternative hypothesis is accepted. Therefore, liquidity, leverage, and financial solvency have a statistically significant impact on profitability of Jordanian industrial enterprises listed on the Amman Stock Exchange as measured by ROA.

More specifically, the results for the relationship between liquidity and profitability of Jordanian industrial enterprises listed on the Amman Stock Exchange (as measured by ROA) show that there is no statistically significant impact of liquidity (measured by the current ratio and quick ratio) on profitability. This finding supports Owais (2016) and Ehiedu (2014), whereas contradicts Khidmat and Rehman (2014), who showed a statistically significant impact of liquidity on profitability; it also contradicts Yusoff (2017) who found that liquidity has a negative effect on profitability.
Concerning the relationship between leverage and profitability of Jordanian industrial enterprises listed on the Amman Stock Exchange (as measured by ROA), it is found that leverage (measured by the debt ratio and the debt-to-equity ratio) has a statistically significant negative impact at the $1 \%$ level of significance on profitability. This finding supports Al-Ali (2018) and Kanaan and Saoud (2018) whereas it contradicts Aliwi (2019).

Regarding the relationship between financial solvency and profitability of Jordanian industrial enterprises listed on the Amman Stock Exchange (as measured by ROA), it was found that financial solvency (measured by interest coverage ratio) has no statistically significant effect on profitability. This result is in agreement with Owais (2016) and Yusoff (2017).

Table 6 presents the outcomes of the regression analysis of the effect of the independent variables on the dependent variable (ROE). The multiple regression equation was adopted by the method of constant estimates as indicated by the Hausman test.

Table 6. Results of HO2-1-HO2-3 testing

\begin{tabular}{|c|c|c|c|c|}
\hline \multicolumn{5}{|c|}{ The dependent variable: ROA } \\
\hline Variable & Coefficient & Std. Error & t-Statistic & Prob. \\
\hline C & -1082.101 & 554.9015 & -1.950077 & 0.0522 \\
\hline$C . R$ & -14.79332 & 19.70503 & -0.750738 & 0.8040 \\
\hline$Q . R$ & -3.420703 & 13.7675 & -0.248462 & 0.4535 \\
\hline$D . R$ & -3.020357 & 0.831508 & -3.632386 & $0.0003 * * *$ \\
\hline$D / E$ & -46.01746 & 0.167646 & -274.4921 & $0.0000 * * *$ \\
\hline I.C.R & 0.000171 & 0.004873 & 0.035151 & 0.9720 \\
\hline C.SIZE & 167.4216 & 75.56238 & 2.215674 & $0.0276 * *$ \\
\hline$R$-squared & \multicolumn{4}{|c|}{0.697} \\
\hline $\begin{array}{l}\text { Adjusted } \\
R \text {-square }\end{array}$ & \multicolumn{4}{|c|}{0.676} \\
\hline F-statistic & \multicolumn{4}{|c|}{1904.704} \\
\hline Prob. & \multicolumn{4}{|c|}{$0.0000 * * *$} \\
\hline
\end{tabular}

Note: $*, * *$, and $* * *$ denotes acceptance of the hypothesis at the $10 \%, 5 \%$, and $1 \%$ levels, respectively.

Table 6 shows the acceptance of the statistical mod$\mathrm{el}$, as the value of Sig is reached. The F-Statistics factor is 0.00000 . This indicates that the statistical model is acceptable at the level of $1 \%$ and that the study variables are consistent with each other to a high degree, as the adjusted $\mathrm{R} 2$ value indicated by $67.6 \%$, which means that the independent variables in the study model explained an amount of $67.6 \%$ of the change in ROE. Based on the above, 


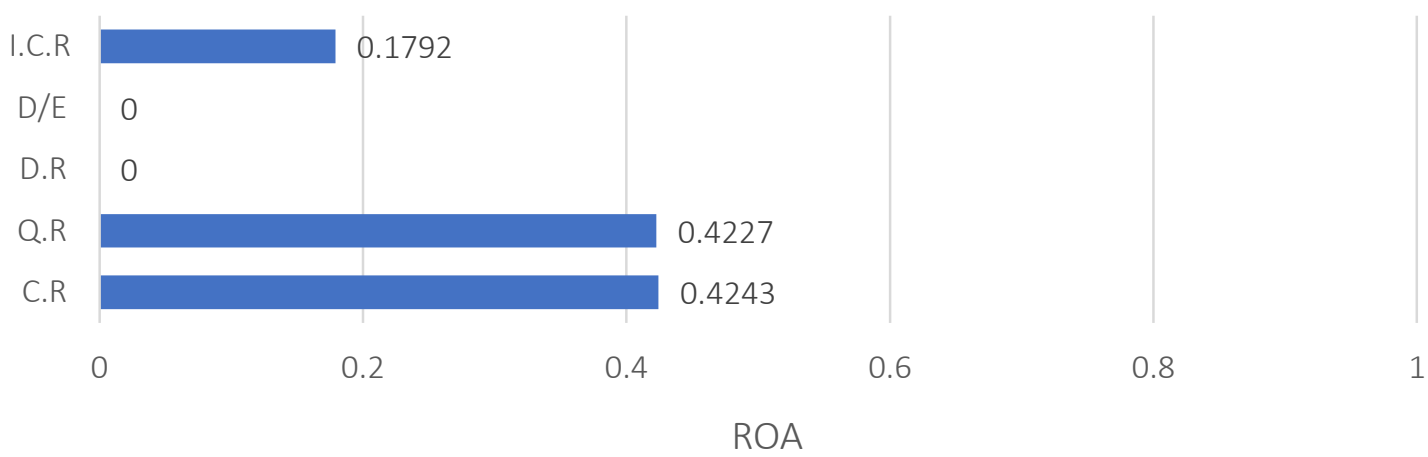

Figure 2. The relative impact of solvency, leverage, and liquidity on ROA

the main null hypothesis is rejected: "Liquidity, leverage, and financial solvency have no statistically significant impact on profitability of Jordanian industrial enterprises listed on the Amman Stock Exchange as measured by ROE". The alternative hypothesis is accepted: "Liquidity, leverage, and financial solvency have a statistically significant impact on profitability of Jordanian industrial enterprises listed on the Amman Stock Exchange as measured by ROE".

More specifically, the results of the relationship between liquidity and profitability of Jordanian industrial enterprises listed on the Amman Stock Exchange (as measured by ROE) indicate that there is no statistically significant effect of liquidity (measured by the current ratio and quick ratio) on profitability. This finding supports Owais (2016) and Ehiedu (2014), whereas contradicts Khidmat and Rehman (2014), and Yusoff (2017).

Concerning the relationship between leverage and profitability of Jordanian industrial enterprises listed on the Amman Stock Exchange (as measured by ROE), it was found that there is a statistically significant negative impact at the $1 \%$ level of significance of leverage (measured by the debt ratio and the debt-to-equity ratio) on profitability. This finding supports Aliwi (2019), Al-Ali (2018), and Kanaan and Saoud (2018).

Regarding the relationship between financial solvency and profitability of Jordanian industrial enterprises listed on the Amman Stock Exchange (as measured by ROE), it was found that financial solvency (measured by interest coverage ratio) has no statistically significant impact on profitability. This result is in agreement with Owais (2016) and Yusoff (2017).

\subsection{Relative impact of solvency, leverage, and liquidity on profitability}

The results in Figure 2 show the relative impact of solvency, leverage, and liquidity on profitability in terms of ROA.

Results show that leverage with its two measures (debt ratio and debt-to-equity ratio) has the highest relative effect among the independent variables, with the significance value Sig $=0.0000$ for both debt ratio and debt-equity ratio.

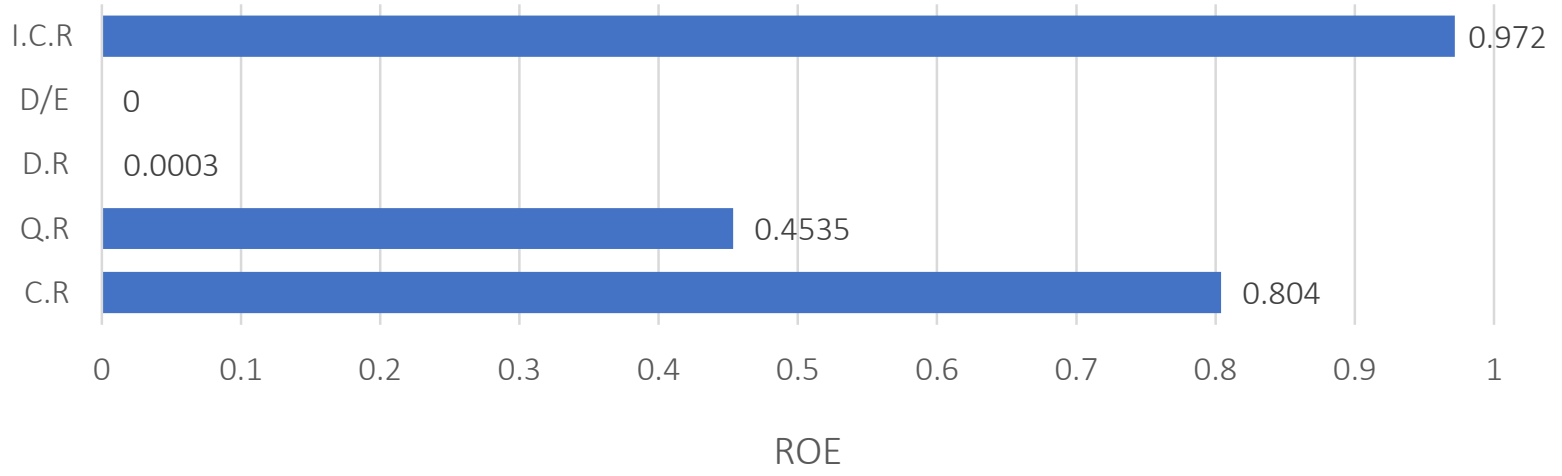

Figure 3. The relative impact of solvency, leverage, and liquidity on ROE 
Results also show that solvency in terms of the interest coverage ratio follows leverage, as the value of the significance reached Sig $=0.1792$ and then liquidity in its measures (the current ratio and the quick ratio) when the significance value reached Sig $=0.4243$ for the current ratio and the significance value was Sig $=0.4227$ for the quick ratio.

Figure 3 shows the relative impact of liquidity, leverage, and solvency on ROE.

Results show that financial leverage with its two measures (debt ratio and debt-to-equity ratio) has the highest relative effect among the independent variables when the significance value Sig $=0.0000$ for the debt-to-equity ratio and the significance value $\operatorname{Sig}=0.0003$ for the debt ratio.

Results also show that liquidity in its two measures (the current ratio and the quick ratio) follows the financial leverage, as the value of the significance reached Sig $=0.804$ for the current ratio and the value of the significance reached Sig $=0.4535$ for the quick ratio of liquidity. This is followed by the financial solvency in its measure the interest coverage ratio, where the value of the indication is Sig. $=0.972$.

\section{CONCLUSION}

The study indicates that financial solvency, leverage, and liquidity have a statistically significant impact on profitability of Jordanian industrial enterprises listed on the Amman Stock Exchange (measured by ROA and ROE). The company size is considered a control variable for the relationship among liquidity, leverage, solvency, and profitability.

More specifically, results for the relationship between liquidity and profitability of Jordanian industrial enterprises listed on the Amman Stock Exchange (measured by ROA and ROE) indicate that liquidity does not have a statistically significant influence on profitability, as measured by the current ratio and quick ratio.

Concerning the relationship between leverage and profitability of Jordanian industrial enterprises listed on the Amman Stock Exchange (measured by ROA and ROE), it was found that leverage (measured by the debt ratio and the debt-to-equity ratio) has a statistically significant negative impact on profitability at the $1 \%$ level of significance.

Regarding the relationship between solvency and profitability of Jordanian industrial enterprises listed on the Amman Stock Exchange (measured by ROA and ROE), it was found that solvency (measured by interest coverage ratio) has no statistically significant effect on profitability.

Finally, concerning the relative impact of liquidity, financial leverage, and financial solvency on profitability (measured by ROA), it was found that financial leverage has the highest relative impact among the independent variables, followed by financial solvency and then liquidity. Concerning the relative impact of liquidity, financial leverage, and solvency on profitability (measured by ROE), the results also show that financial leverage has the highest relative impact among the independent variables followed by liquidity and then solvency.

\section{RECOMMENDATIONS}

Following the results of this paper regarding the existence of a statistically significant negative relationship between leverage and profitability measured by ROA and ROE in Jordanian industrial enterprises, management is recommended to pay attention to reduce reliance on debt in financing the company. This ensures achieving the highest possible returns for companies. 
In addition, based on what is reached in this study regarding the existence of a negative impact of most liquidity ratios on ROA and ROE, the study recommends all Jordanian industrial enterprises to work on maintaining an acceptable level of liquidity. This ensures that the continuity of companies is not threatened, on the one hand, and allows them to achieve acceptable levels of profits, on the other hand, by increasing the optimum utilization of current assets and investing them in order to maximize profits.

Regarding the existence of a positive relationship between financial solvency and profitability, management must pay attention to the level of financial solvency within the companies to maintain high financial performance, whether to achieve returns on their assets or for their shareholders.

The study also recommends that management must reconsider the optimal financing policies and work to increase reliance on internal sources of financing due to the ease of obtaining them and their low degree of risk, then resorting to external financing sources to cover the remaining deficit in needs.

Moreover, more future studies should be conducted using other sectors and variables that were not examined in this study to show their impact on the profitability of companies to benefit managers, investors, and decision-makers.

\section{AUTHOR CONTRIBUTIONS}

Conceptualization: Maha D. Ayoush.

Data curation: Maha D. Ayoush, Khaled I. Shabaneh.

Formal analysis: Maha D. Ayoush, Khaled I. Shabaneh.

Investigation: Maha D. Ayoush, Khaled I. Shabaneh.

Methodology: Maha D. Ayoush, Khaled I. Shabaneh.

Project administration: Maha D. Ayoush, Ahmad A. Toumeh.

Resources: Maha D. Ayoush, Ahmad A. Toumeh, Khaled I. Shabaneh.

Supervision: Maha D. Ayoush.

Validation: Maha D. Ayoush, Ahmad A. Toumeh.

Visualization: Maha D. Ayoush.

Writing - original draft: Maha D. Ayoush, Khaled I. Shabaneh.

Writing - review \& editing: Maha D. Ayoush, Ahmad A. Toumeh.

\section{REFERENCES}

1. Akenga, G. (2017). Effect

of liquidity on financial performance of firms listed at the Nairobi Securities Exchange, Kenya. International Journal of Science and Research, 6(7), 279285. Retrieved from https://www. ijsr.net/get_abstract.php?paper_ id $=$ ART20175036

2. Al-Ali, A. (2018). The effect of financial leverage on liquidity and profitability: An applied study on a sample of companies listed on the Damascus Securities Exchange. Al-Baath University Journal, 40(1), 173-205. (In Arabic). Retrieved from http:// search.mandumah. com/Re- cord/901271
3. Ali, M. (2014). Relationship between Financial Leverage and Financial Performance (Evidence of Listed Chemical Companies of Pakistan). Research Journal of Finance and Accounting, 5(23), 4656. Retrieved from https://citeseerx. ist.psu.edu/viewdoc/download?d oi $=10.1 \cdot 1.662 .9837 \&$ rep $=$ rep $1 \&$ ty $\mathrm{pe}=\mathrm{pdf}$

4. Aliwi, N. (2019). The effect of financial leverage on the financial performance of the Jordanian public joint-stock companies listed on the Amman Financial Market (Master Thesis). Middle East University.

5. Al-Jafari, M. K., \& Samman, H. A. (2015). Determinants of profitability: evidence from industrial companies listed on Muscat Securities Market. Review of European Studies, 7(11). https:// doi.org/10.5539/res.v7n11p303

6. Baum, C. F., Schäfer, D., \& Talavera, O. (2006). The Effects of Short-Term Liabilities on Profitability: The Case of Germany (DIW Discussion Papers No. 635). German Institute for Economic Research. Retrieved from https://econpapers.repec.org/ paper/diwdiwwpp/dp635.htm

7. Bhatt, S., \& Verghese, N. (2018). Influence of Liquidity on Profitability: Evidence from Nepalese Banks. International 
Journal of Multidisciplinary and Current Research, 6, 1085-1090. http://dx.doi.org/10.14741/ ijmcr/v.6.5.13

8. Bitar, M., Saad, W., \& Benlemlih, M. (2016). Bank risk and performance in the MENA region: The importance of Capital requirements. Economic Systems, 40(3), 398-421. https://doi. org/10.1016/j.ecosys.2015.12.001

9. Chang, C. C., Batmunkh, M. U., Wong, W. K., \& Jargalsaikhan, M. (2019). Relationship between capital structure and profitability: Evidence from Four Asian Tigers. Journal of Management Information and Decision Sciences, 22(2), 54-65. Retrieved from https://www.abacademies.org/ articles/relationship-betweencapital-structure-and-profitability-evidence-from-four-asiantigers-8086.html

10. Dahiyat, A. (2016). Does Liquidity and Solvency Affect Banks Profitability? Evidence from Listed Banks in Jordan. International Journal of Academic Research in Accounting, Finance and Management Sciences, 6(1), 35-40. Retrieved from https://ideas.repec. org/a/hur/ijaraf/v6y2016i1p35-40. html

11. Durrah, O., Rahman, A. A. A., Jamil, S. A., \& Ghafeer, N. A. (2016). Exploring the relationship between liquidity ratios and indicators of financial performance: An analytical study on food industrial companies listed in Amman Bursa. International Journal of Economics and Financial Issues, 6(2). Retrieved from https:// www.econjournals.com/index. php/ijefi/article/view/2045

12. Ehiedu, V. C. (2014). The impact of liquidity on profitability of some selected companies: the financial statement analysis (FSA) approach. Research Journal of Finance and Accounting, 5(5), 81-90. Retrieved from https://core. ac.uk/download/pdf/234629826. pdf

13. Gujarati, D. N. (2009). Basic econometrics. New Delhi: Tata McGraw-Hill Education.
14. Kanaan, A., \& Saoud, A. (2018). The effect of financial leverage on profitability - An applied study on non-financial companies listed on the Damascus Stock Exchange. Economic and Legal Sciences Series, 40(3), 265-280. Retrieved from http://journal.tishreen.edu. sy/index.php/econlaw/article/ view/4651/4421 (in Arabic language)

15. Kebewar, M. \& Shah, S. M. N. A. (2012). The effect of debt on corporate profitability: Evidence from French service sector (MPRA Paper No. 43304). Munich Personal RePEc Archive. Retrieved from https://mpra.ub.unimuenchen.de/43304/

16. Khidmat, W., \& Rehman, M. (2014). Impact of Liquidity and Solvency on Profitability Chemical Sector of Pakistan. Economics Management Innovation, 6(3), 34-67. Retrieved from http:// emijournal.cz/wp-content/ uploads/2020/08/01_waqas_bin_ khidmat_mobeen_ur_rehman_impact_of_liquidity_solvency_ on_profitability.pdf

17. Madushanka, K. H. I., \& Jathurika, M. (2018). The impact of liquidity ratios on profitability (With special reference to Listed Manufacturing Companies in Sri Lanka). International Research Journal of Advanced Engineering and Science, 3(4), 157-161. Retrieved from https://zenodo.org/ record/2539287\#.YS4bl44zbIU

18. Mohanty, B., \& Mehrotra, S. (2018). Relationship between liquidity and profitability: An exploratory study of SMEs in India. Emerging Economy Studies, 4(2), 169-181. https://doi.org /10.1177\%2F2394901518795069

19. Nguyen, T. N. L., \& Nguyen, V. C. (2020). The Determinants of Profitability in Listed Enterprises: A Study from Vietnamese Stock Exchange. The Journal of Asian Finance, Economics and Business, 7(1), 47-58. https://doi. org/10.13106/jafeb.2020.vol7. no1.47

20. Owais, W. (2016). Examination of the effect of liquidity and solvency on the profitability of industrial companies - An empirical study: Jordanian industrial companies. Journal of Studies in Economics, Trade and Finance, 5(1), 73-90. Retrieved from https://www.asjp. cerist.dz/en/article/21629 (in Arabic language)

21. Rudin, M., Nurdin, D., \& Fattah, V.Y. (2016). The Effect of Liquidity and Leverage on Profitability of Property and Real Estate Company in Indonesian Stock Exchange. International Journal of Social Sciences and Management, 3(4), 300-304. http://dx.doi. org/10.3126/ijssm.v3i4.15964

22. Saleh, I., Abu Afifa, M., \& Murray, L. (rev.ed.). (2020). The effect of credit risk, liquidity risk and bank capital on bank profitability: Evidence from an emerging market. Cogent Economics \& Finance, 8(1), 1814509. https:// doi.org/10.1080/23322039.2020.1 814509

23. Sarwat, S., Iqbal, D., Durrani, B. A., Shaikh, K. H., \& Liaquat, F. (2017). Impact of working capital management on the profitability of firms: Case of Pakistan's cement sector. Journal of Advanced Management Science, 5(3). Retrieved from http://www.joams. com/index.php? $\mathrm{m}=$ content $\& \mathrm{c}=$ in $\operatorname{dex} \& \mathrm{a}=$ show $\&$ catid $=64 \& \mathrm{id}=375$

24. Shahzad, F., Fareed, Z., \& Zulfiqar, B. (2015). Impact of working capital management on firm's profitability: A case study of cement industry of Pakistan. European researcher, 91(2), 86-93. http://dx.doi. org/10.13187/er.2015.91.86

25. Sudiyanto, B., Puspitasari, E., Suwarti, T., \& Asyif, M. M. (2020). Determinants of Firm Value and Profitability: Evidence from Indonesia. The Journal of Asian Finance, Economics, and Business, 7(11), 769-778. https:// doi.org/10.13106/jafeb.2020.vol7. no11.769

26. Yusoff, H.B.M. (2017). The Effect of Liquidity and Solvency on Profitability: The Case of Public-Listed Consumer Product Companies in Malaysia (Master Thesis). University Tun Hussein Onn Malaysia. 